\title{
INVESTIMENTO DIRETO EXTERNO E DESENVOLVIMENTO ECONÔMICO AFRICANO: ESTUDO DE CASO DA ECONOMIA \\ MOÇAMBICANA
}

\author{
Sílvio Antônio Ferraz Cário ${ }^{1}$ \\ Eduardo Saugineta Sigaúque ${ }^{2}$
}

\begin{abstract}
RESUMO: O artigo tem como objetivo discutir o papel do IDE no processo de industrialização da economia Moçambicana. Os principais setores indústrias (têxtil, caju, borracha, vidro, etc.) que detinham entre as décadas de 1970-1980 uma participação significativa na divisão internacional e regional do trabalho foram enceradas ou privatizadas ao longo da década de 1990. No campo produtivo, notou-se que em 2015 , cerca de $80 \%$ das exportações do país estavam sob controle das empresas multinacionais. Apesar do país ter sido o segundo maior destino de capitais externos, na forma de IDE na África Subsaariana, à contribuição média dos megaprojetos no Produto Interno Bruto (PIB) não superou $2 \%$ a.a. A pesquisa constatou com base na visão teórica da dependência que o Estado Moçambicano tornou-se um ao longo das últimas duas décadas (1995-2015) um "Estadoempresário", refletindo no nível de endividamento público externo. Entretanto, pelas características estruturais das economias periféricas, a burguesia local encontra-se subordinado aos interesses do capital financeiro mundial e por isso dá primazia aos ganhos de participação acionária minoritárias nos megaprojetos, em detrimento de uma idealização e criação de um projeto de desenvolvimento próprio e sustentado de longo prazo para o país.
\end{abstract}

Palavras-chaves: Desenvolvimento Econômico, IDE, Moçambique.

ABSTRACT: The article aims to discuss the role of FDI in the process of industrialization of the Mozambican economy. The major industrial sectors (textiles, cashew, rubber, glass, etc.) that had significant participation in the international and regional division of labour between the 1970s and 1980s were waxed or privatized throughout the 1990s. In the productive field, it was noted that by 2015 , about $80 \%$ of the country's exports were under the control of multinational companies. Although the country was the second largest foreign capital destination, in the form of FDI in subSaharan Africa, the average contribution of megaprojects in the Gross Domestic Product (GDP) did not exceed $2 \%$ a.a. Based on the theoretical view of dependence, the survey found that the Mozambican state has become a "business-state" over the last two decades (1995-2015), reflecting the level of external public indebtedness. However, due to the structural characteristics of peripheral economies, the local bourgeoisie is subordinated to the interests of the world's financial capital and therefore gives priority to the minority shareholding gains in megaprojects, to the detriment of an idealization and creation of a development project of its own. Long-term sustainability for the country.

Keywords: Economic Development, FDI, Mozambique.

\footnotetext{
${ }^{1}$ Doutor em Ciências Econômicas pela Universidade Estadual de Campinas (UNICAMP) e Professor Titular do Departamento de Economia e Relações Internacionais da Universidade Federal de Santa Catarina (UFSC). E-mail: fecario@yahoo.com.br

${ }^{2}$ Mestre em Economia pela Universidade Federal de Santa Catarina (UFSC) e Economista no Ministério do Mar, Águas Interiores e Pescas da República de Moçambique. E-mail: edyy.morgan@gmail.com
} 


\section{INTRODUÇÃO}

Nas décadas de 1960 e 1970, com a proclamação das independências nacionais, a maior parte dos países africanos escolheu o modelo socialista como estratégia ideológica de desenvolvimento. Não obstante, a luta pela supremacia do modelo de desenvolvimento socialista em Moçambique, e total disponibilidade do país continuar no "campo socialista", em 1980 viu rejeitado o pedido adesão ao Conselho Econômico de Ajuda Mútua. Esta rejeição à impactou os vários projetos estruturantes que o Estado planejava levar a cabo para superar o subdesenvolvimento.

Desta forma, as ocorrências desses fatos históricos contribuíram para que o país iniciasse uma reaproximação diplomática com os países Ocidentais. E, em setembro de 1984, formalmente, o país foi aceite como membro do Fundo Monetário Internacional (FMI) e Banco Mundial e marcou o passo inicial para a instauração da economia do mercado. No final da década de 1990 e início da década de 2000, Moçambique registrou um aumento do fluxo líquido de Investimento Direto Externo (IDE). De acordo com os dados do Banco Mundial (2015), nos últimos quinze anos (2000-2015), o país recebeu um valor acumulado de US\$ 1.2 bilhões em IDE, equivalente a média anual de US\$ 109 milhões.

O IDE esteve concentrado nos setores intensivos em capital e tecnologia, da indústria extrativa (mais de 48\%), nos chamados megaprojetos, de alumínio (Mozal), carvão mineral (Vale do Rio Doce e Rio Tinto), energia elétrica (Hidroelétrica de Cahora Bassa) e gás natural (SASOL- Empresa Sul Africana de Gás e Petróleo). A atração de capital internacional no país, através de fixação de bases produtivas pelas empresas multinacionais em território nacional foi definida como "uma das estratégias de desenvolvimento econômico”. Deste modo, no período em consideração, Moçambique configurou como um dos três principais destinos preferenciais de IDE na África Subsaariana (África do Sul, Moçambique e Nigéria).

Nas décadas de 1970 e 1980, vários cientistas sociais da África, de entre eles, o Claude Ake (1980), inspirados nas visões teóricas dos cientistas da CEPAL - Comissão Econômica para América Latina e Caribe apresentaram vários estudos sobre dependência no processo de desenvolvimento econômico dos países africanos. Não obstante esse esforço analítico havia um erro metodológico que sempre prevalecia nas pesquisas sobre o fenômeno da dependência na África. Segundo Devés-Valdés (2012, p.145) os cientistas conheciam pouco ou nada da trajetória do próprio pensamento social e econômico africano, e isso fez com que, buscassem interpretações fundamentalmente embasadas mais às escolas internacionais, à economia do desenvolvimento, ao marxismo e ao dependentismo.

O presente artigo busca apresentar uma compreensão analítica da dinâmica do IDE na região da África Subsaariana, tomando como caso de estudo, a economia moçambicana. Ciente do fato de que o país configurou nas últimas décadas como uma das regiões preferências de capitais externos de África. 


\section{TRATAMENTO TEÓRICO}

A CEPAL representa a primeira corrente-estruturalista que buscou uma interpretação sobre o fenômeno do desenvolvimento dos países de capitalismo tardio. Furtado (2009) reconhece que o subdesenvolvimento é uma fase autônoma não sendo necessariamente uma fase em que os países centrais tenham passado. Tal pressupõe inevitavelmente uma crítica aos modelos de universalização o processo e a forma de desenvolvimento. Para tanto, propõe uma ordenação dos fatores primários no processo desenvolvimento autônomo ou dependente.

Conclui-se que existe uma inversão dos fatores de produção, sendo que nas economias autônomas, o progresso tecnológico é a chave para a acumulação de capital e mudança estrutural do perfil da demanda. Nos países dependentes existe uma inversão da ordenação dos fatores primários, por tratar de países permeáveis ao IDE, ocorre à modificação do perfil da demanda interna seguindo o processo de acumulação ditado pelos países centrais. As contribuições de CARDOSO E FALLETO (1979) que consideram que o desenvolvimento econômico é antes de mais, um processo social. Em relação ao papel da tecnologia e do capital financeiro mundial no processo de desenvolvimento dependente, os autores aludem que as pressões políticas no final são os interesses de grupos ou classes que irão definir a forma de desenvolvimento do país periférico. Mesmo assim, os autores consideram que a abertura das economias periféricas ao capital externo constitui uma estratégia-chave para a industrialização e própria sobrevivência das classes dominantes.

$\mathrm{Na}$ perspectiva analítica dos autores, através da atração das empresas multinacionais é possível desenvolver a periferia e expandir um setor industrial forte que ofereça possibilidades e desenvolvimento de um mercado interno forte. Por outro lado, CARDOSO E FALLETO reconhecem o caráter da marginalização absoluta causada pela expansão das empresas multinacionais nos países dependentes. Os efeitos sociais, como desvio das prioridades de investimento básico para a sociedade é um dos elementos negativos do efeito demonstração que os países dependentes tendem a sofrer com aumento de fluxos de capitais externos.

A corrente marxista representada pelas contribuições teóricas de Bambirra (2015) e Marini (2000) apresenta uma crítica ao sistema de produção capitalista. Bambirra (2015) considera que a inserção tardia das economias dependentes no processo de industrialização não ofereceu alternativas para o desenvolvimento tecnológico nacional e acumulação da poupança interna; em razão disso, esses países mostraram permeáveis ao IDE. O aumento da produtividade de trabalho nas economias centrais proporcionou a expansão produtiva das empresas multinacionais para as regiões periféricas, em busca da mais-valia relativa. Neste processo, tais empresas buscam explorar a força de trabalho abundante-reserva de força de trabalho através de pagamentos de baixos salários, elevação da composição do valor de capital. 


\section{DINÂMICA DO COMÉRCIO EXTERNO - ÁFRICA SUBSAARIANA}

A dinâmica no comércio externo tem sido resultado das transformações estruturais ocorridas na capacidade produtiva interna dos países. Deste modo, o comportamento das taxas de exportações e importações sinalizam as modificações na estrutura produtiva. O crescimento das exportações e o progressivo estreitamento do hiato em relação às importações resultaram da transformação da estrutura das exportações. Na África Subsaariana o crescimento das exportações e das importações não seguiu o padrão tipo de modificações estruturais no processo de desenvolvimento.

Desta forma, tomando por base o comportamento das exportações e importações constante no Gráfico 3.11, nota-se que no período entre 1960-2015, as exportações corresponderam à média anual de 27,36\%; e, por sua vez, as importações registraram à média anual de 27,8\%. De modo geral, considera-se que se registrou um déficit percentual médio anual no saldo da balança comercial de $0,48 \%$ nas últimas cinco décadas.

Gráfico 3.11: Exportações e Importações, Saldo da Balança Comercial (\% do PIB) África Subsaariana (1960-2015)

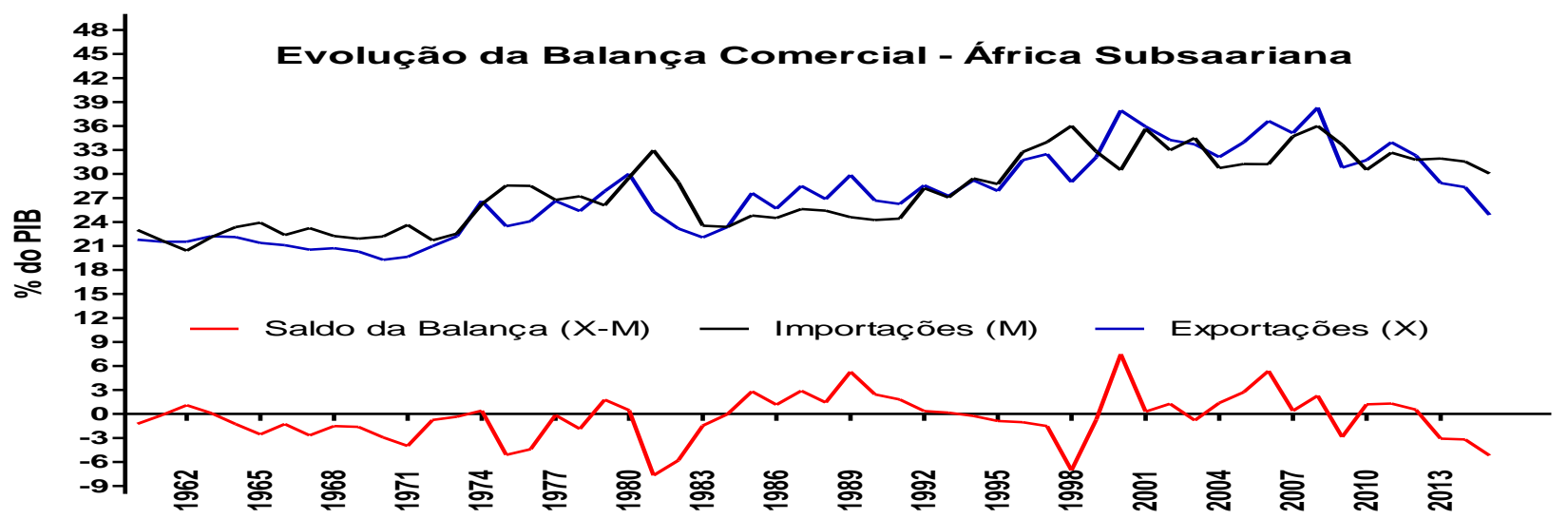

Fonte: Elaborado pelo autor com base nos dados do Banco Mundial (2015).

Tomando como base o comportamento dos indicadores macroeconômicos do Gráfico 3.12, observa-se que período de 1960-2015, a África Subsaariana registrou períodos de déficit e superávit no saldo da balança comercial. Durante cinco décadas, a África Subsaariana acumulou déficits no saldo da balança comercial, a saber: na década de 1960 teve déficit médio anual de 1,1\% do PIB; na década de 1970 apresentou déficit médio anual de 1,7\%; na década de 1980 alcançou déficit médio anual de 0,09\%; e por fim na década de 1990 registrou um déficit médio anual de 0,7\%. Na década de 2000, a África Subsaariana alcançou um superávit médio anual no saldo da balança comercial de $1,8 \%$. 
Gráfico 3.22: Exportações (\% do PIB), União Europeia, América Latina, África Subsaariana e Mundo (1960-2015)

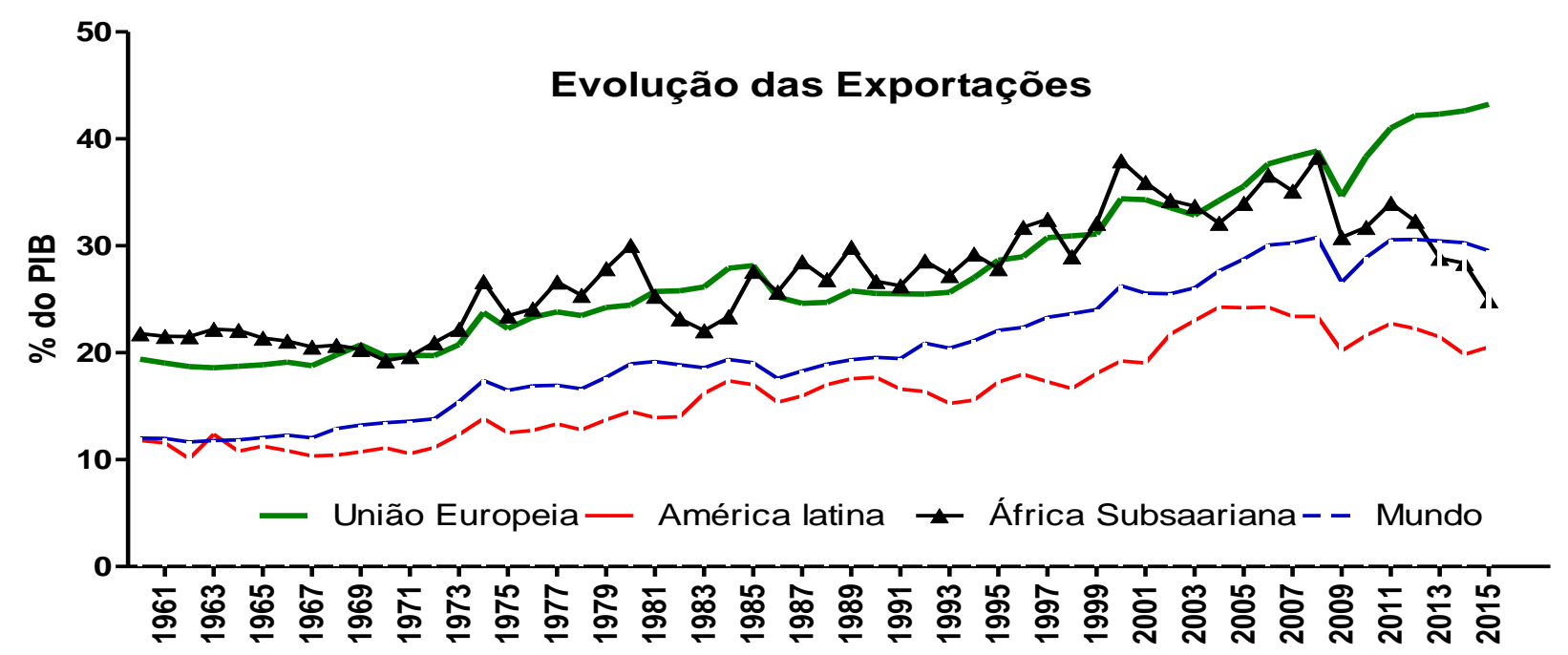

Fonte: Elaborado pelo autor com base nos dados do Banco Mundial (2015).

Gráfico 3.13: Importações (\% do PIB), União Europeia, América Latina, África Subsaariana e Mundo (1960-2015)

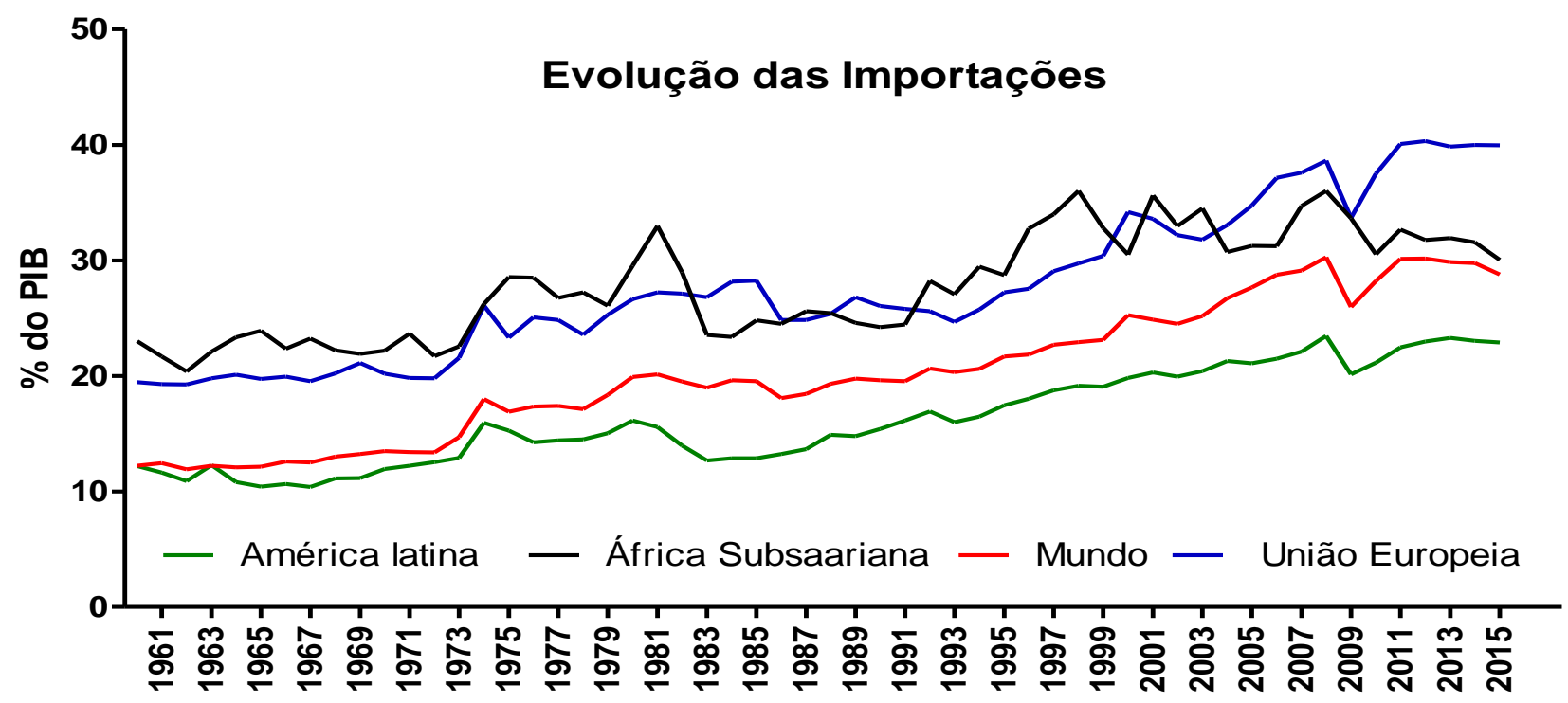

Fonte: Elaborado pelo autor com base nos dados do Banco Mundial (2015).

No período de 1960-2015 as exportações médias anuais da América Latina corresponderam a $16 \%$ do Produto Interno Bruto (PIB), enquanto na União Europeia a média foi de $28 \%$. No mesmo período, a média anual das exportações mundiais representaram 20\% do PIB Mundial. Os dados do Gráfico 3.14 mostram que na década de 1960 a taxa média anual das exportações mundial foi $12 \%$. Portanto, na África Subsaariana as exportações médias representaram $21 \%$ do PIB, e na América latina e União Europeia foram de $11 \%$ e de $19 \%$, respetivamente. Durante as últimas décadas (1960- 
2015), as exportações do mundo aumentaram em média de 16\%. No que tange a variação percentual das exportações por região, a União Europeia registrou o maior aumento das exportações no total percentual do PIB, tendo obtido 16,3\%, seguida pela África Subsaariana que aumentou das exportações na ordem de $14 \%$ a.a., e a América Latina registrou aumento de $11 \%$ a.a. No Gráfico 3.14, também se constatou que em 2015 as exportações mundiais corresponderam a 28\% do PIB; e, a África Subsaariana alcançou 35\%; América Latina conseguiu 22\% e a União Europeia a $35 \%$. Latina registaram no mesmo período, superávit médio de $0,08 \%$ e $0,04 \%$ do PIB, respetivamente.

As importações médias anuais mundiais, no período de 1960-2015 alcançaram 20\% do PIB. No período selecionado a América Latina apresentou importações médias de 16\%, todavia a União Europeia e a África Subsaariana registaram importações médias de $28 \%$ a.a. e $29 \%$ a.a., respetivamente. Nas últimas cinco décadas (1960-2015), constatou-se que em termos reais houve aumento em $17 \%$ das importações mundiais. Entretanto, no mesmo período em análise a União Europeia apresentou maior aumento relativo das importações no total do PIB, 21\%; a América Latina de $11 \%$; e, a África Subsaariana, 7\%. Analisando o comportamento dos saldos da balança comercial nota-se que no período de 1960-2015, a balança comercial mundial apresentou um superávit médio de $0,12 \%$ do PIB. No período selecionado, a África Subsaariana registrou déficit médio na balança comercial de $0,48 \%$ do PIB. A União Europeia e a América.

Gráfico 3.14 Balança Comercial (\%), União Europeia, América Latina, África Subsaariana e Mundo -

(1960-2015)

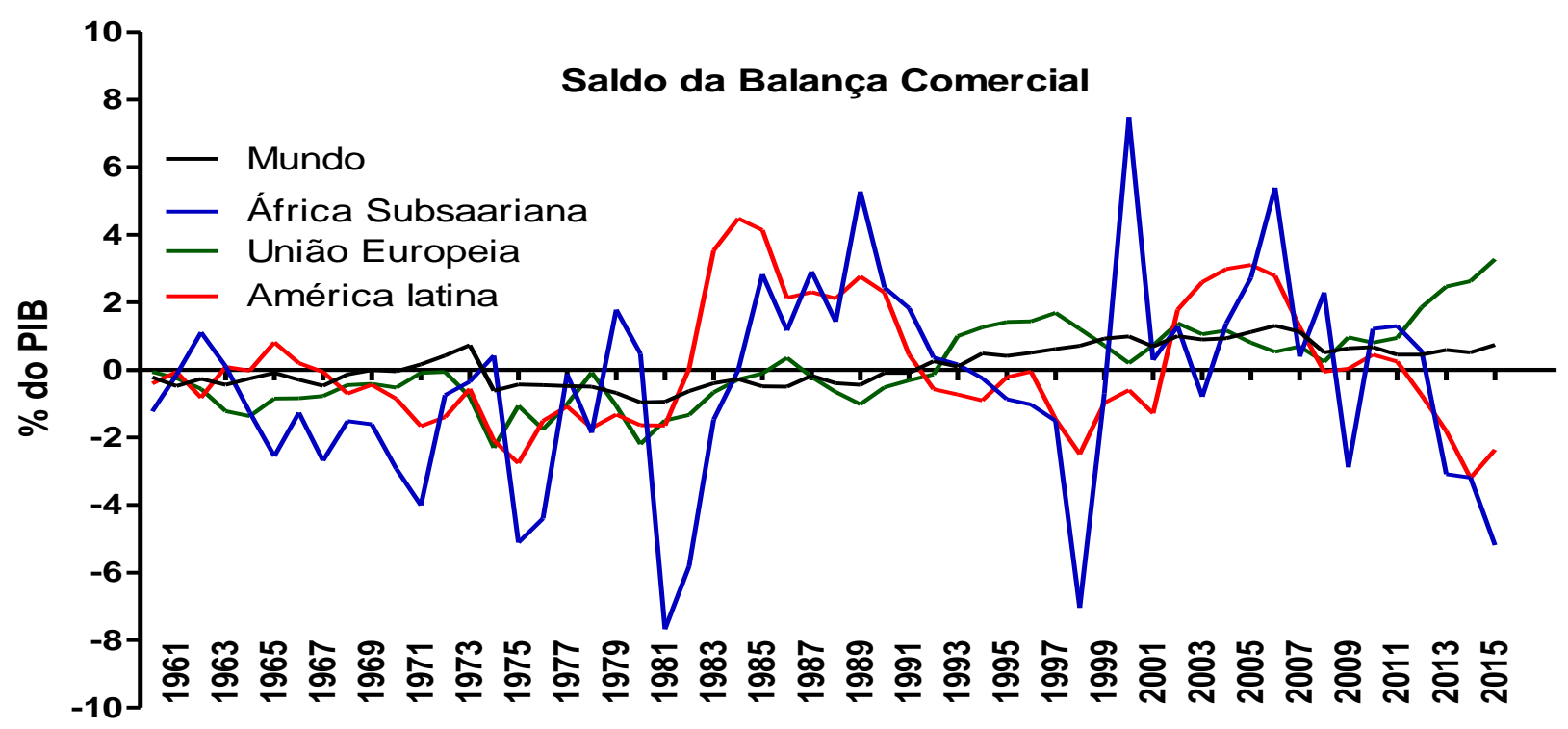

Fonte: Elaborado pelo autor com base nos dados do Banco Mundial (2015). 
Na década de 1960, a África Subsaariana registrou déficit médio de 1,10\% do PIB, enquanto a América Latina e a União Europeia apresentaram déficits médios anuais no saldo da balança comercial de $0,14 \%$ e 0,68\% do PIB, respetivamente. Na década de 1970 a África Subsaariana registrou aumento médio anual de $0,66 \%$ do déficit comercial. Nesta década de 1960, o valor percentual do déficit comercial na África Subsaariana foi de 1,7\% do PIB. Os dados do Gráfico 3.16 mostram que a América Latina apresentou um déficit de 1,5\%, representando um aumento médio de 1,4\% a.a., comparativamente a situação da década de 1960. A União Europeia teve déficit médio anual de $0,88 \%$ do PIB, que representou aumento médio anual de $0,20 \%$ em comparação a década de 1960. De acordo com o comportamento do saldo da balança comercial, a década de 1980 foi o período em que se verificou uma diminuição dos níveis de déficits em todas as regiões selecionadas. A África Subsaariana apresentou redução do saldo médio deficitário em 1,7\% do PIB, e apresentou saldo médio anual do déficit da balança comercial de 0,09\%, ao longo da década de 1980.

Desta forma, ao longo da década de 1990 a União Europeia na registrou saldo positivo na balança comercial. Obteve um superávit comercial de 0,77\% do PIB, na década de 1990 . Na década de 2000, todas as regiões selecionadas apresentaram superávits no saldo da balança comercial. A África Subsaariana teve médio anual de superávit de 1,8\% do PIB, enquanto que a América Latina apresentou saldo médio anual superavitário de 1,3\% do PIB. Não obstante o fato da América Latina e a África Subsaariana terem obtido aumento médio anual no saldo da balança comercial em 1,7\% e 2,4\%, respetivamente, a União Europeia apresentou um saldo menor a, o saldo de 0,77\% do PIB, conforme o Gráfico 3.17. A participação da África Subsaariana no comércio mundial foi composta de produtos primários de valor agregado em tecnologia. Segundo os dados da Tabela 3.6, no período de 1960-2015, o montante médio anual das exportações da África Subsaariana foi de US\$ 108 bilhões. Este montante correspondeu à participação média anual da África Subsaariana no comércio externo de $2 \%$ no comércio mundial. A África Subsaariana teve uma participação média muito menor no comércio mundial quando comparado com a América Latina e União Europeia.

\section{INVESTIMENTO DIRETO EXTERNO - ÁFRICA SUBSAARIANA}

De acordo com os dados do Gráfico 3.15, no período de 1970-2015, os fluxos líquidos de IDE que se direcionaram para a África Subsaariana, com respeito ao PIB foram em média de dois pontos percentuais. De acordo com o Gráfico 3.20, no período de 1970-2015, os fluxos líquidos de IDE que se direcionaram para a África Subsaariana, com respeito ao PIB foram em média de dois pontos percentuais. Entretanto, o estoque acumulado de capital externo, em termos líquidos de IDE atingiu US $\$ 497$ bilhões, no período considerado. Nestes termos, houve entrada média anual de IDE no valor de US\$ 10.8 bilhões. A África Subsaariana não foi a principal região receptora de fluxo de IDE no 
mundo. De acordo com dados do Banco Mundial, a União Europeia atraiu uma média de $40 \%$ a.a. de IDE e na América Latina, foi na média de $10 \%$ a.a. do fluxo mundial de IDE.

Os dados da Tabela 3.1 mostram que o estoque acumulado, em termos líquidos de IDE na União Europeia foi de US\$ 12.8 trilhões. O valor líquido acumulado de IDE na União Europeia representou entrada média anual de US\$ 278 bilhões. No período selecionado, o estoque acumulado de IDE na América Latina foi de US\$ 3.3 trilhões, o que representou uma entrada líquida média anual de IDE no valor de US\$ 72 bilhões.

Gráfico 3.15: Fluxo Líquido de IDE- União Europeia, América Latina, África Subsaariana - (1970-2015)

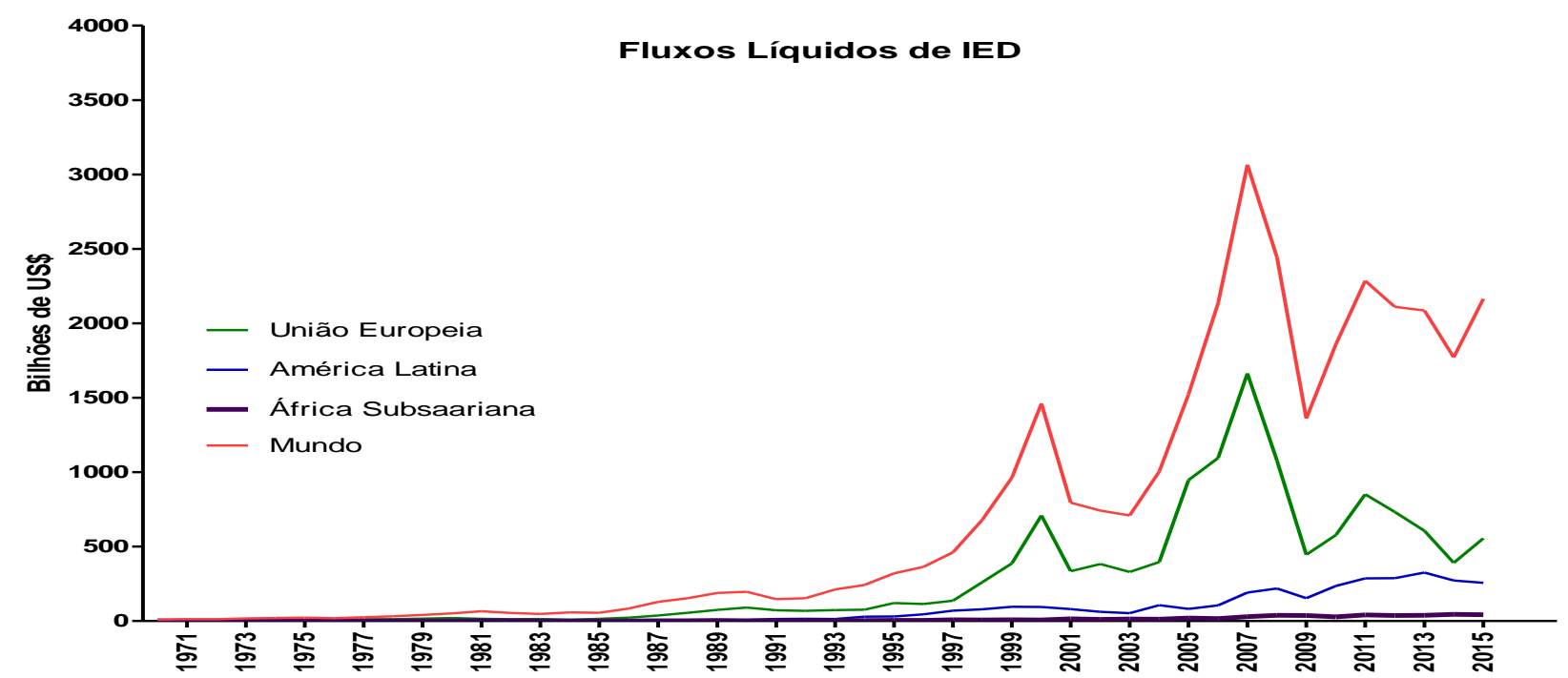

Fonte: Elaborado pelo autor com base nos dados do Banco Mundial (2015).

Tabela 3.1: Fluxo Líquido de IDE (bilhões US\$) - União Europeia, América Latina, África Subsaariana (2004-2015).

\begin{tabular}{|l|l|l|l|l|l|l|l|}
\hline Região & \multicolumn{2}{|l|}{ União Europeia } & \multicolumn{2}{l|}{ América Latina } & África Subsaariana & Mundo \\
\hline Ano & Fluxo Líquido & $\begin{array}{l}\% \text { IDE } \\
\text { Mundial }\end{array}$ & $\begin{array}{l}\text { Fluxo } \\
\text { Líquido }\end{array}$ & $\begin{array}{l}\% \text { no IDE } \\
\text { Mundial }\end{array}$ & $\begin{array}{l}\text { Fluxo } \\
\text { Líquido }\end{array}$ & $\begin{array}{l}\% \text { no IDE } \\
\text { Mundial }\end{array}$ & $\begin{array}{l}\text { Fluxo } \\
\text { Líquid } \\
\text { o }\end{array}$ \\
\hline 2004 & 395 & $39 \%$ & 106 & $11 \%$ & 12 & $1 \%$ & 1.004 \\
\hline 2005 & 946 & $62 \%$ & 81 & $5 \%$ & 19 & $1 \%$ & 1.522 \\
\hline 2006 & 1.095 & $51 \%$ & 104 & $5 \%$ & 16 & $1 \%$ & 2.136 \\
\hline 2007 & 1.663 & $54 \%$ & 190 & $6 \%$ & 30 & $1 \%$ & 3.065 \\
\hline 2008 & 1.077 & $44 \%$ & 218. & $9 \%$ & 39 & $2 \%$ & 2.443 \\
\hline 2009 & 445 & $33 \%$ & 153 & $11 \%$ & 37 & $3 \%$ & 1.360 \\
\hline 2010 & 577 & $31 \%$ & 236 & $13 \%$ & 28 & $2 \%$ & 1.858 \\
\hline 2011 & 851 & $37 \%$ & 285 & $13 \%$ & 41 & $2 \%$ & 2.285 \\
\hline 2012 & 733 & $35 \%$ & 288 & $14 \%$ & 37 & $2 \%$ & 2.110 \\
\hline 2013 & 606 & $29 \%$ & 326 & $16 \%$ & 38 & $2 \%$ & 2.086 \\
\hline 2014 & 392 & $22 \%$ & 272 & $15 \%$ & 44 & $3 \%$ & 1.771 \\
\hline 2015 & 555 & $26 \%$ & 256 & $12 \%$ & 42 & $2 \%$ & 2.164 \\
\hline
\end{tabular}

Fonte: Elaborado pelo autor com base nos dados do Banco Mundial (2015). 
A leitura dos valores sobre o Fluxo Líquido de IDE permite afirmar que a partir de 2004, registrou-se um aumento no fluxo de IDE no mundo. Neste contexto, a União Europeia no ano 2005 recebeu em torno de US\$ 1 trilhão em IDE (62\% do fluxo mundial). No entanto, A crise financeira e econômica internacional de 2007/2008 provocou uma severa retração de IDE nos países desenvolvidos, em especial na União Europeia, fato que contribuiu para uma redução média anual de 2\% no fluxo de entrada de IDE. Em contrapartida, a América Latina registrou aumento médio anual de $0,5 \%$ no fluxo de entrada de IDE. Nestes termos, houve entrada média anual de IDE no valor de US\$ 10.8 bilhões. A África Subsaariana não foi a principal região receptora de fluxo de IDE no mundo. De acordo com dados do Banco Mundial, a União Europeia atraiu uma média de 40\% a.a. de IDE e na América Latina, foi na média de $10 \%$ a.a. do fluxo mundial de IDE.

Os dados da Tabela 3.7 mostram que o estoque acumulado, em termos líquidos de IDE na União Europeia foi de US\$ 12.8 trilhões. O valor líquido acumulado de IDE na União Europeia representou entrada média anual de US\$ 278 bilhões. No período selecionado, o estoque acumulado de IDE na América Latina foi de US\$3.3 trilhões, o que representou uma entrada líquida média anual de IDE no valor de US\$ 72 bilhões. A leitura dos valores sobre o Fluxo Líquido de IDE permite afirmar que a partir de 2004, registrou-se um aumento no fluxo de IDE no mundo. Neste contexto, a União Europeia no ano 2005 recebeu em torno de US\$ 1 trilhão em IDE (62\% do fluxo mundial). No entanto, A crise financeira e econômica internacional de 2007/2008 provocou uma severa retração de IDE nos países desenvolvidos, em especial na União Europeia, fato que contribuiu para uma redução média anual de $2 \%$ no fluxo de entrada de IDE. Em contrapartida, a América Latina registrou aumento médio anual de $0,5 \%$ no fluxo de entrada de IDE.

\section{INVESTIMENTO DIRETO EXTERNO E INDUSTRIALIZAÇÃO EM MOÇAMBIQUE}

Xiong (2010) IDE está estreitamente ligado aos megaprojetos - projetos de grande escala que são detidos por estrangeiros, frequentemente no setor dos recursos naturais. O presente capítulo procura analisar o motivo pelo qual o IDE tem maioritariamente assumido a forma de megaprojetos em Moçambique e em que medida esses projetos poderão levar a mais emprego e crescimento no futuro. Moçambique configura na lista dos três países da região da África Subsaariana que recebeu maior fluxo financeiro de IDE nos últimos 15 anos (2000-2015), totalizando entradas líquidas no valor de US\$ 30 bilhões em IDEs.

No período de 1970-1999, o país recebeu valor líquido de US\$932 milhões em IDE. Em média de fluxo de IDE, no período de 2000-2015 foi de US\$ 529 milhões, valor superior, a média, de US\$4.2 milhões do referente ao período de 1970-1999. Na década de 1970, por sua vez, o país teve um fluxo 
líquido de IDE no valor de US\$10 milhões em IDE, mas em contrapartida na década de 1980, registou o menor fluxo de IDE, da história recente do país, quando teve uma redução total líquida de US\$8 milhões, isto em comparação com o fluxo líquido verificado na década de 1970. E nisso na década de 1980, o fluxo de entrada líquida de IDE foi de aproximadamente US\$2.2 de IDE.

Na década de 1980, Moçambique enfrentava diversos problemas de índole social, económico e político, criando instabilidade que impactou na captação de IDE. O Programa de Reabilitação Econômica do FMI e Banco Mundial empreendeu reformas estruturais significativas que colocaram o país como um dos destinos preferenciais de IDEs em África. E com isso na década de 2000, o país recebeu um fluxo líquido total de US\$3.7 bilhões em IDE. A década de 2000 representou uma retomada de entrada líquida de IDE no país, mesmo com a crise político-militar, pós-eleitoral que o país atravessa desde as eleições de 2014, mantem-se uma tendência de aumento de fluxo de IDE.

Gráfico 3.16: IDE, entradas e saídas líquidas (US\$) - Moçambique - (1970-2015

IDE, entradas líquidas (US\$)

IDE, a saída líquida (US\$)
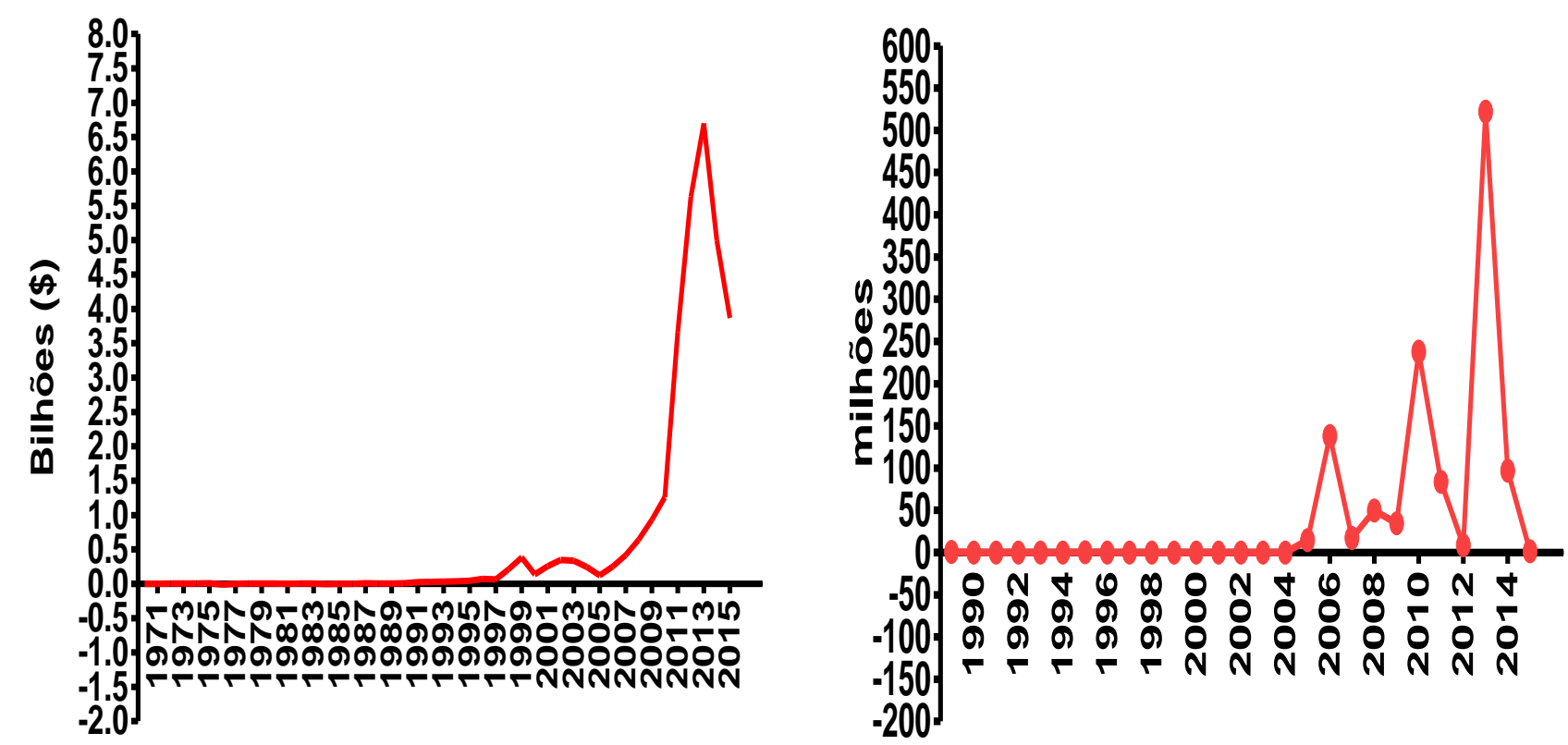

Fonte: Elaborado pelo autor com base nos dados do Banco Mundial (2015).

Os dados dos primeiros cinco anos (2010-2015), da década de 2010, apontam um fluxo de entradas líquidas de US\$26 bilhões em IDE. De 1980-2015, os fluxos de entradas líquidas de IDE foram de $2 \%$ do PIB. O percentual do IDE no PIB veem aumentando ao longo das décadas, os dados da década de 1980, apontam para uma contribuição, média, de 0,06\% no PIB. Mas, por conseguinte, na década de 1990, registou-se um aumento de 1,41\%, passando o fluxo líquido de IDE a representar 1,47\% do PIB de Moçambique. A década de 2000, representou um salto quantitativo significativo no que concerne, a importância do IDE no PIB do país, representando 5\% do PIB. 
Os dados sobre o fluxo de IDE neste período já demostram o aumento de entradas que contribui para a maior contribuição do IDE no PIB nacional. E a tendência crescente de aumento de IDE na economia, os dados dos últimos cinco anos (2010-2015), demostram que 29\% (um aumento de $23,78 \%$ ) do PIB é uma composição de fluxo líquido de IDEs. De outro lado, Moçambique apresenta-se como dos países com saídas líquidas de IDE, significa que existe um investimento em outras regiões do mundo, com capitais moçambicanos.

Os dados do Banco Mundial apontam que em 1989, já existia saído líquido de IDE, no total de US\$940 milhões, valor significativo, levando em conta que no mesmo ano o país recebeu um fluxo líquido de US\$ 3.4 milhões em IDE. No entanto, os dados mostram também que existe uma descontinuidade nos investimentos, por exemplo, no período de 1990-1992, não há registo de saídas líquidas de IDE. De 1994-1995, procede-se retomada de saída de capitais do país para IDE, em cerca de US\$ 228 milhões, no entanto, esse fluxo líquido de saídas de IDE, volta a ser interrompido, entre 1996 e 2004. Nos últimos 15 anos (2005-2015), o fluxo de saídas líquidas de IDEs, totalizou cerca de US\$1.2 bilhões, o que remete a uma média anual de US\$47 milhões.

No que tange as saídas líquidas de IDE no PIB, ainda é insignificante, como atestam os valores de fluxos líquidos de IDE em milhões de dólares. Em termos médios, entre 1980 e 2015, as saídas líquidas de fluxo de IDE representaram cerca 0,19\% do PIB. Nos últimos 15 anos (2000-2015) foi o período em que houve registo de maior saída de IDE, perfazendo 0,43\% do PIB. Em outras décadas (1980 e 1990) não apresentam valores substâncias, na década de 1990 foi apenas de 0,01\%, e com as descontinuidades nos fluxos de saídas líquidas de IDE, que já foram mencionadas.

Gráfico 3.17: IDE (\% do PIB) SADC (Comunidade para o Desenvolvimento da África Austral) - (1970-2015)

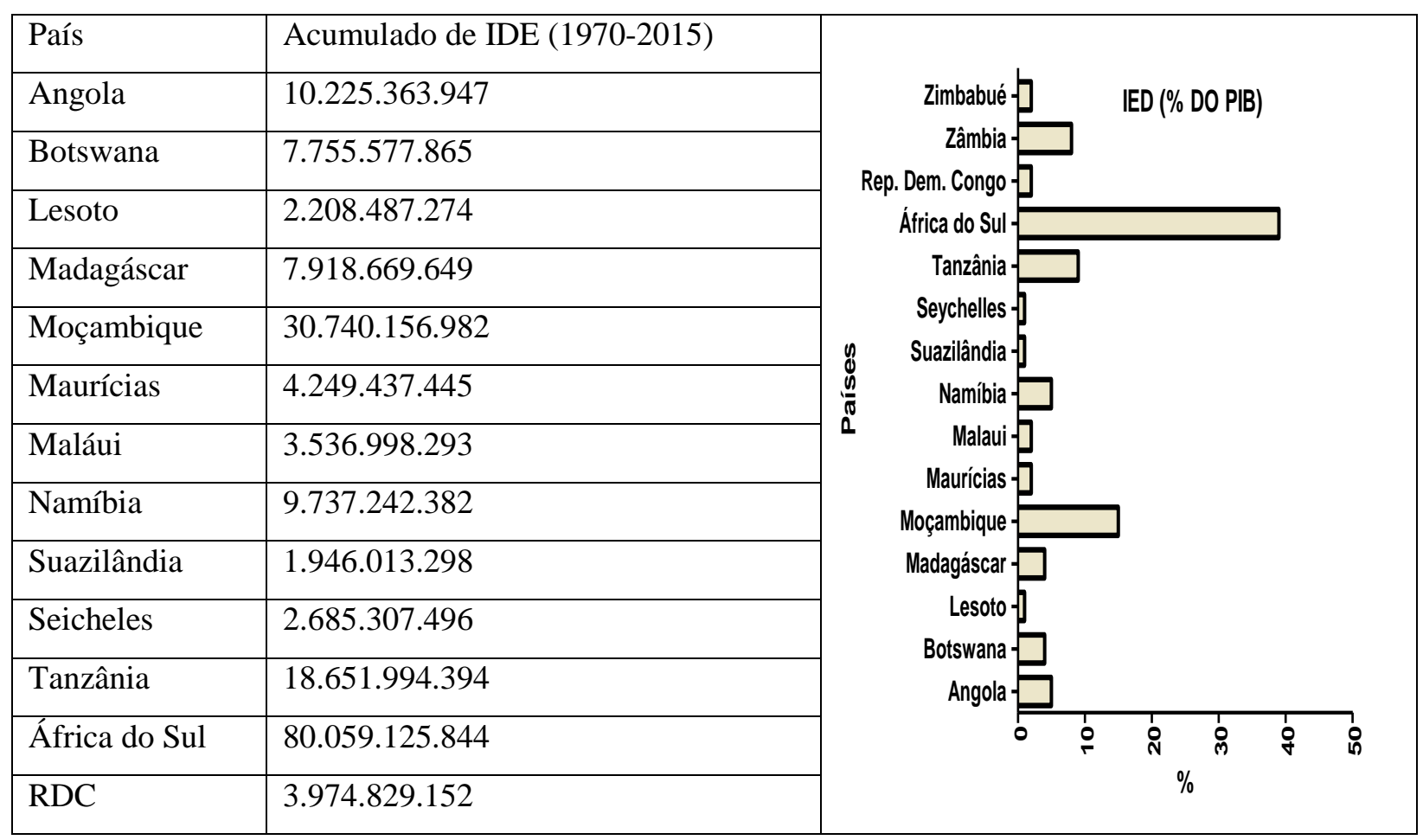




\begin{tabular}{|l|l|l|}
\hline Zâmbia & 17.202 .846 .666 & \\
\cline { 1 - 2 } Zimbabwe & 3.536 .540 .771 & \\
\hline
\end{tabular}

Fonte: Elaborado pelo autor com base nos dados do Banco Mundial (2015).

De acordo com a leitura dos dados do Gráfico 3.17, a SADC, recebeu um total acumulado de US\$ 204.4 bilhões em IDE, no período de 1970-2015. Desde modo, no período considerado, o primeiro destino preferencial de IDE na SADC foi à África do Sul, que recebeu 39\% de IDE total, no valor acumulado de US\$ 80.5 bilhões; e, em segundo lugar, esteve Moçambique com 16\%, cerca de US 30.7 bilhões em IDE. Uma das características do IDE em Moçambique foi que o mesmo esteve direcionado aos setores primários da economia. Os setores da indústria extrativa, do carvão mineral, de energia e do gás foram os que receberam maior volume de capital externo, aproximadamente $48 \%$ da entrada total do IDE.

O aumento do fluxo de IDE em Moçambique foi impulsionado pelas reformas estruturais e conjunturais propostas pelo FMI e Banco Mundial, à margem das políticas neoliberais, ancoradas pelo "Consenso de Washington". Em Agosto de 1984, antes da adesão do país às instituições de Bretton Woods foi aprovada a primeira Lei de Investimento Nacional e Estrangeiro, Lei número 4/84, que marcou o primeiro quadro legal para entrada de capitais estrangeiros em Moçambique. Aqui, cabe realçar que, a constituição de 1975, no seu artigo 14, consagrava que o capital estrangeiro poderá ser autorizado a operar no quadro da política econômica do Estado.

Como forma de outorgar a participação da burguesia nacional no processo de acumulação, foi aprovado o regulamento da Lei de Investimentos Nacionais, pela Lei número 5/87, de 19 de janeiro de 1993. No ano de 1993, o Conselho de Ministros de Moçambique aprovou a Lei de Investimentos Estrangeiro 3/93, de 24 de Junho, instrumento jurídico que estabeleceu o quadro legal básico e uniforme para entrada de IDE no país. Assim sendo, nota-se que no período entre 1984 a 1993, houve esforço institucional para criar todas as condições legais e fiscais de atração de capitais externos para o país. Um dos resultados das políticas neoliberais propostas pelo FMI e Banco Mundial foi à criação de ambiente macroeconômico para entrada de capitais externos. Entretanto, a entrada de IDE nas economias dependentes segue a dinâmica do processo de acumulação capitalista mundial. Na concepção analítica de Bambirra (2015, p.156) "a inserção tardia dos países periféricos no sistema capitalista mundial, já os torna permeável ao IDE”.

Segundo Castelo-Branco (2008, p.2) os megaprojetos são área quase exclusiva de intervenção de grandes empresas multinacionais por causa dos elevadíssimos custos, das qualificações e especialização requeridas, das condições competitivas e especialização dos mercados fornecedores e consumidores. Conforme a Tabela 5.2, os principais megaprojetos operando em Moçambique são: 
Em 1997, o primeiro megaprojeto instalado em Moçambique, foi do consórcio nipônicoaustraliano e sul-africano, a MOZAL (Mozambique Aluminium) para a fundição de alumínio em Maputo e o investimento total foi de US\$ 1.3 bilhão. Em 2004, o segundo megaprojeto foi da multinacional sul-africana, a SASOL (Suis Africanas Steenkool en Olie ${ }^{3}$ ) para a exploração dos jazigos de gás natural em Pande e Temane na província de Tete e o investimento total foi de ZAR 10 bilhões (US\$ 758 milhões preços correntes). Em 2004, o terceiro megaprojeto instalado foi da empresa brasileira, a VALE DO RIO DOCE para a exploração dos jazigos de carvão mineral na província de Tete e o investimento total foi de US\$ 1.322 bilhões. Em 2012, ocorreu à reconversão da HIDROELÉTRICA DE CAHORA BASSA para o Estado Moçambicano, de capitais acionários moçambicanos participaram $85 \%$ e o português com $15 \%$ e cujo valor de investimento do Estado foi de US\$ 700 milhões.

Tabela 5. 1: Estrutura Acionista dos Megaprojetos de investimento em Moçambique (1997, 2004, 2008)

\begin{tabular}{|c|c|c|c|}
\hline Megaprojetos & Setor & Estrutura Acionista & A Participação do Estado Moçambicano \\
\hline $\begin{array}{l}\text { MOZAL } \\
(1997)\end{array}$ & $\begin{array}{l}\text { Fundição de } \\
\text { Alumino }\end{array}$ & $\begin{array}{l}\text { Japão ( } 25 \% \text { pela Mitsubishi), } \\
\text { Austrália ( } 47 \% \text { pela BHP Billiton), } \\
\text { África do Sul ( } 24 \% \text { pela IDC) e } \\
\text { Moçambique ( } 4 \% \text { pelo Estado } \\
\text { Moçambicano) }\end{array}$ & $\begin{array}{l}\text { A participação acionária de } 4 \% \text { do Estado } \\
\text { Moçambicano no megaprojeto de fundição } \\
\text { de alumínio foi possível através do } \\
\text { empréstimo de US\$ } 20 \text { milhões no Banco } \\
\text { Europeu de Investimentos (BCI) }\end{array}$ \\
\hline $\begin{array}{l}\text { SASOL } \\
(2004)\end{array}$ & $\begin{array}{l}\text { Exploração } \\
\text { de Gás } \\
\text { Natural }\end{array}$ & $\begin{array}{l}\text { África do Sul ( } 70 \% \text { pela SASOL) e } \\
\text { o Estado Moçambicano ( } 30 \% \text { pela } \\
\text { EHM - Empresa de } \\
\text { Hidrocarbonetos de Moçambique). }\end{array}$ & $\begin{array}{l}\text { A participação acionaria de } 30 \% \text { do Estado } \\
\text { Moçambicano no megaprojeto da } \\
\text { exploração do gás natural foi possível por } \\
\text { meio de um empréstimo de US\$ } 74 \text { milhões } \\
\text { (Fase 1- US\$24 milhões (2003) e na Fase } 2 \\
\text { - US\$ } 50(2010) \text { ). }\end{array}$ \\
\hline $\begin{array}{l}\text { VALE DO } \\
\text { RIO DOCE } \\
\quad(2004)\end{array}$ & $\begin{array}{c}\text { Exploração } \\
\text { de Carvão }\end{array}$ & $\begin{array}{l}\text { Brasil (70\% Vale Moçambique), } \\
\text { Japão (15\% pela Mitsubishi), } \\
\text { Estado Moçambicano (5\% } \\
\text { Empresa Moçambicana de } \\
\text { Exploração Mineira (EMEM)) e os } \\
\text { 10\% (investidores nacionais). } \\
\end{array}$ & $\begin{array}{l}\text { A participação do Estado Moçambicano no } \\
\text { megaprojeto do através de financiamento } \\
\text { interno nos bancos comerciais } \\
\text { (estrangeiros) que operam em Moçambique. }\end{array}$ \\
\hline $\begin{array}{l}\text { Hidroelétrica } \\
\text { de Cahora } \\
\text { Bassa } \\
(2007)\end{array}$ & $\begin{array}{l}\text { Geração de } \\
\text { Eletricidade }\end{array}$ & $\begin{array}{c}\text { Moçambique ( } 85 \% \text { Estado } \\
\text { Moçambicano) e Portugal }(15 \% \\
\text { pela Rede Elétrica Nacional - } \\
\text { REN). }\end{array}$ & $\begin{array}{c}\text { O Estado Moçambicano para adquirir a } \\
\text { participação maioritária no megaprojeto da } \\
\text { HCB contraiu um empréstimo de US\$ } 700 \\
\text { milhões junto a um sindicato constitui-o } \\
\text { pelo banco Francês Crédit Agricole Lyon e } \\
\text { o banco Português BPI - Banco Português } \\
\text { de Investimentos. }\end{array}$ \\
\hline
\end{tabular}

Fonte: Elaborado pelo autor com base nos dados do Ministério das Finanças

\footnotetext{
${ }^{3}$ Tradução livre de “Afrikaans" para "Português” - Empresa de Carvão e Óleo da África do Sul.
} 
A Tabela 5.2 sugere que a participação acionária do Estado Moçambicana nos megaprojetos de investimento foi menor. Excetuando-se, a partir de 30 de Dezembro de 2007, quando o Estado Moçambicano passou a ter uma participação majoritária na Hidroelétrica de Cahora Bassa. Todavia, mesmo que país detenha em termos percentuais maior parte das ações da Hidroelétrica de Cahora Bassa, quando se analisa a arquitetura financeira que conduziu a reversão, nota-se que o país ainda não tem detém o controle de capitais do megaprojeto. Visto que, para proceder ao pagamento da reversão total ao Estado Português, o país recorreu aos empréstimos em bancos estrangeiros (França e Portugal). Assim, observa-se o Estado contraiu um empréstimo de US\$ 700 milhões para proceder à reconversão da Hidroelétrica de Cahora Bassa no Banco Francês (Crédit Agricole Lyon) e Português (Banco Português de Investimentos) amortização prevista para dez anos (20012-2022). Deste modo, a entrada das empresas multinacionais no país obrigou ao endividamento público externo e constitui um fator limitante a capacidade de criação de projeto de desenvolvimento autônomo em longo prazo. Deste modo, Moçambique possui diversos recursos naturais com elevado potencial para promover o desenvolvimento socioeconômico, mas devido à escassez de capital e ausência de tecnologia avançada para impulsionar o processo produtivo mostra-se permeável à entrada de capitais externos. Assim, o país não possui capacidade financeira e tecnológica para proceder às transformações necessárias na estrutura produtiva que ofereçam possibilidades de promover um desenvolvimento próprio e sustentado. Como Furtado (2011, p.104) elencou:

“As possibilidades de desenvolvimento econômico dos países encontram-se no progresso tecnológico, pois este aumenta a produtividade dos fatores físicos, apoiada no processo de acumulação, conduzindo os países para modificações na estrutura do perfil da demanda".

O funcionamento dos megaprojetos em Moçambique vai ao encontro da própria dinâmica de acumulação capitalista mundial. Porém, priorização estratégica do Estado aos megaprojetos para promover o desenvolvimento econômico limita o próprio processo de acumulação interna, na medida em que são concedidos estímulos fiscais para atração e barateamento dos investimentos que ao mesmo tempo, impactam na capacidade de arrecadação tributária do Estado para suprimir as suas despesas. Assim, uma das principais caraterísticas das empresas multinacionais, principalmente as que investem em setores da indústria extrativa é que são intensivos em capital e tecnologia. Tal fato justifica que as multinacionais demandem grandes quantidades de mão-de-obra de baixa qualificação no período de instalação das unidades produtivas, e quando já estão em pleno funcionamento tendem a demandar mão-de-obra qualificada e especializada. Em Moçambique, a par de muitos países africanos de baixa renda existe um número limitado de pessoas com qualificações especializadas para 
trabalharem nos grandes projetos. E, tal fato, faz com que a maior parte da mão-de-obra especializada que trabalha nos megaprojetos no país seja oriunda dos países de capital originário.

Figura 5.1: Empréstimos para participação do Estado Moçambicanos nos Megaprojetos - 2015

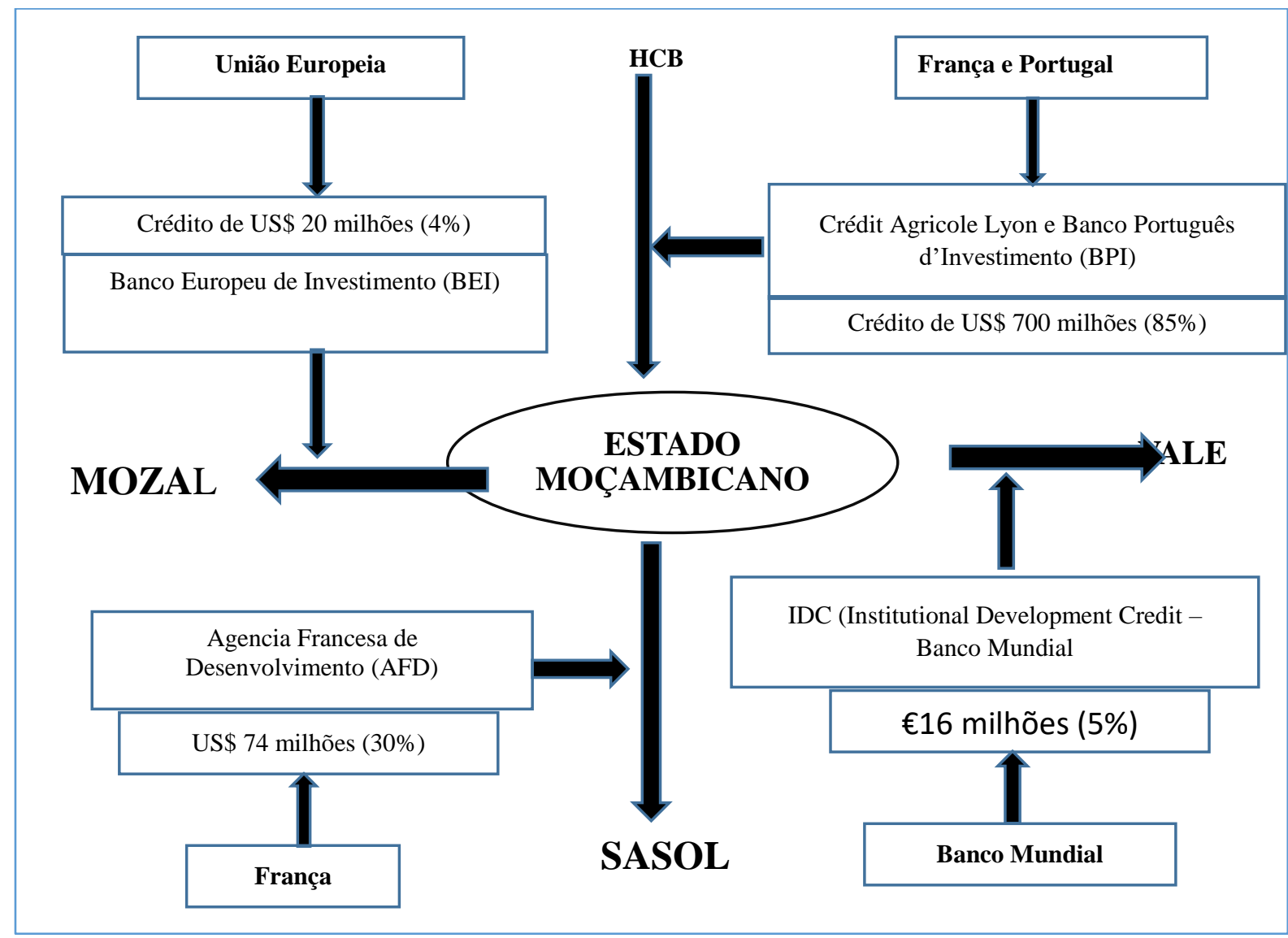

Fonte: Elaborado pelo autor com base na informação do Banco Mundial e da Agência Francesa de Desenvolvimento

De forma excepcional, o megaprojeto de fundição de alumínio da MOZAL por localiza-se na capital DE Moçambique, Maputo, beneficia-se de mão-de-obra qualificada e especializada existente na cidade metropolitana de Maputo, mas de forma contrário, nos megaprojetos de gás natural da SASOL e de geração de energia elétrica da Hidroelétrica de Cahora Basa a maior parte dos trabalhadores era oriunda dos países detentores de capital majoritário. Neste quadro, quando se analisa a estrutura de emprego do país na década de 2000, nota-se claramente que não houve uma variação na taxa real de desemprego. A taxa média de desemprego na faixa etária entre 15-24 anos, nesse período manteve-se na faixa de $23 \%$ a.a. O FMI - Fundo Monetário Internacional (2012, p.35), considera que "o megaprojeto da MOZAL é extremamente intensivo em capital, criando apenas um emprego por cada US\$ 160 mil investidos”. Para Castelo-Branco (2008, p.5) considera que “dado quase todos os megaprojetos serem intensivos em capital, as oportunidades de emprego direto foram relativamente escassas". 
Além da questão de geração de empregos que é crucial para o aumento da renda das famílias, outro fator que merece análise tem a ver com o papel do Estado na criação de mecanismos de arrecadação tributária, para fazer face às despesas de investimentos social e econômico do país. Desta forma, como fora mencionado, os megaprojetos não conseguem se apresentar como plataforma produtiva-industrial para absorver o exército industrial de reserva em torno de 12 milhões de força de trabalho, segundo os dados do Banco Mundial.

Assim, a existência de um Estado forte e eficiente é importante para condução de uma estratégia de desenvolvimento em longo prazo e para reduzir os problemas estruturais ligadas a baixa geração de empregos diretos nos megaprojetos. Deste modo, para minimizar os efeitos de falta de geração de emprego nos megaprojetos, o Estado pode usar-se dos mecanismos legais para aumentar a tributação aos megaprojetos, e proceder por meio disso, financiamento direto aos setores produtivos nacionais. No tocante a contribuição dos megaprojetos na economia nacional nota-se claramente que apesar de aumento do valor líquido de fluxos de IDE, a sua contribuição na economia é menor. De acordo com o Gráfico 5.2 na década de 2000 houve um aumento considerável dos fluxos de IDE, mas sem com isso, significar aumento da contribuição dos megaprojetos. Não obstante, durante a década de 2000 a entrada de IDE no país foi inferior ao do PIB, a partir de 2008 nota-se que a entrada IDE foi superior ao PIB do país.

Gráficos 3.17: Entrada de fluxos de Investimento Externo Direto e PIB em Moçambique - 2000-2010

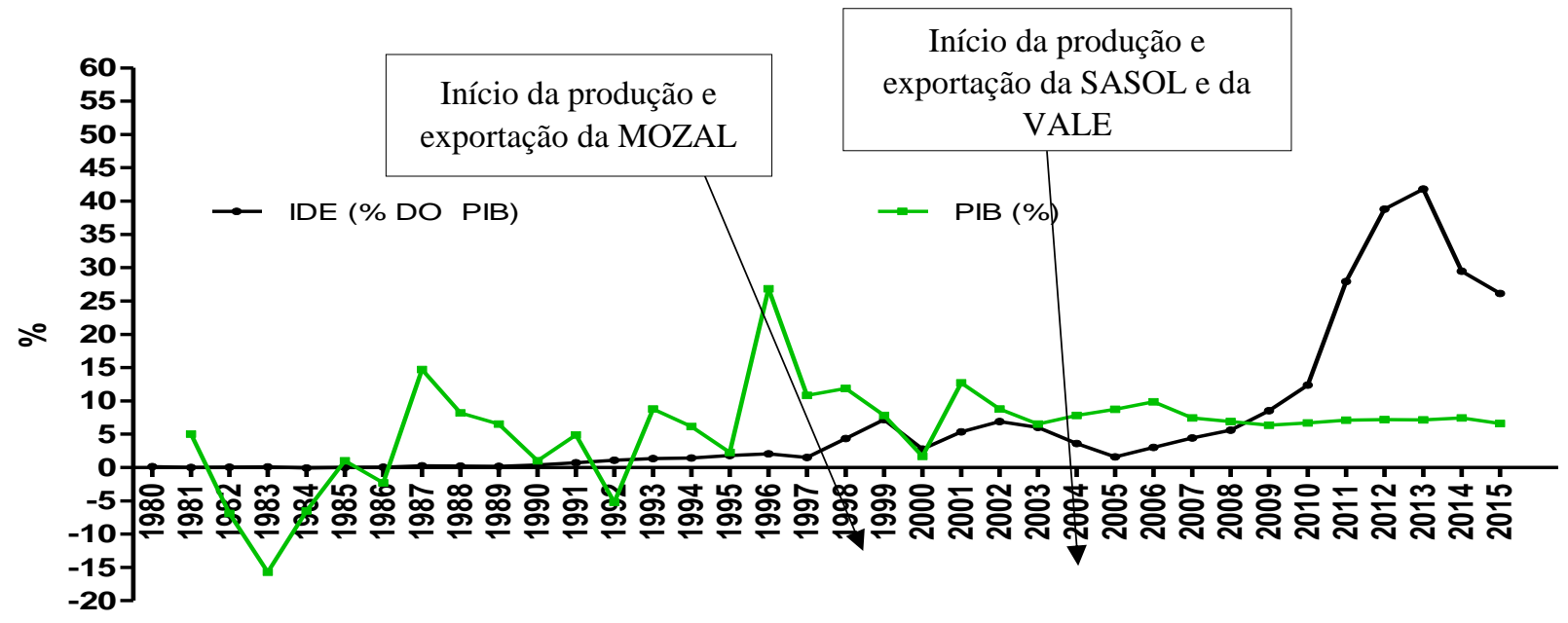

Fonte: Elaborado pelo autor com base nos dados do Banco Mundial (2015).

Desta maneira, para o funcionamento dos megaprojetos houve necessidade do Estado criar as condições básicas, como investimentos em infraestruturas (construção da linha de eletricidade de alta tensão e ampliação do terminal Portuária de Matola) e adequação da legislação fiscal e aduaneira 
$\left(\right.$ Zonas Econômicas Especiais $^{4}$ ) aos interesses das empresas multinacionais. Em termos gerais, houve desvios na priorização dos investimentos públicos para atender aos interesses do capital internacional.

As contribuições tributárias dos megaprojetos nas contas públicas nacionais foram por meio de pagamento do imposto sobre operações relativas à circulação de mercadorias. Na Mozal, o Estado arrecadou US\$ 4 milhões/ano em impostos diretos e US\$ 6 milhões/ano em impostos indiretos (ANDERSON, 2002). Uma vez que, os megaprojetos estão isentos ao pagamento de impostos como realçou ANDERSON (2002), constata-se que financiamento público, via de receita tributária oriundo dos megaprojetos para o desenvolvimento, foi inexistente.

Deste modo, acrescenta-se que os megaprojetos desenvolvidos no país seguem o padrão internacional fundado em concessões fiscais e outros benefícios, cujos lucros, em sua maior parte são repatriados para o país originário do capital. $\mathrm{Na}$ escassez de financiamento interno, o Estado busca atrair financiamento externo e/ou proceder à diminuição das despesas públicas nas áreas sociais e de infraestruturas.

\section{6. Á GUISA DA CONCLUSÃO}

Ao longo do artigo foram analisados quatro (4) megaprojetos - de empresas multinacionais com intuito de buscar compreender as possibilidades de desenvolvimento do país sob a estratégia de captação de poupança externa, de IDE. No entanto, notou-se que o IDE além de ter pouca participação na criação da riqueza nacional, contribui para desvios de formulação de políticas de desenvolvimento nacional. O IDE que fluiu para Moçambique foi direcionado para o setor da indústria extrativa (48\%).

No entanto, dạda a necessidade de contar com infraestrutura moderna e logística eficiente para a operacionalização e escoamento dos produtos/matérias-primas para os mercados internacionais, o Estado teve que criar as condições necessárias para responder a demanda do capital externo. Dentro de uma contradição de desenvolvimento, o Estado ofereceu incentivos fiscais aos megaprojetos, o que em última análise, reduz a possibilidade de auferir receitas tributárias para cobrir as despesas de funcionamento e investimento. Não obstante o aumento de fluxos de investimentos diretos externos, os dados mostram que os níveis de pobreza e de desigualdade na distribuição da renda não tiveram uma alteração significativa ao longo das últimas duas décadas. O fato comprova a visão teórica que apostola o caráter marginalizador do capitalismo dependente.

A dinâmica das exportações nacionais mostrou que as empresas multinacionais selecionadas foram responsáveis por mais de $80 \%$ das exportações. Este dado em per si, mostra que o país está

\footnotetext{
${ }^{4}$ A Zona Econômica Especial de Beluluale foi criada através do Decreto número 45/97, de 23 de Dezembro.
} 
dependente em termos produtivos do IDE. Ao longo da década de 2000 em que se observou aumento nos preços das commodities, o país beneficiou-se de entrada de divisas através das exportações de matérias primas (alumínio, carvão, gás natural), o que contribuiu para diminuir a relação da dívida pública/PIB. A participação acionária do Estado nas empresas multinacionais ainda é muito diminuta. Este fato contribui para que as receitas tributárias do Estado sejam ínfimas. No único megaprojeto em que o Estado ter uma participação majoritária, isto é, na HCB, a mesma foi possível por meio de empréstimos contraídos nos sistemas bancários europeus. E com isso, apesar de ter um controle acionário majoritário, o capital internacional é que extrai o excedente econômico gerado na economia.

Deste modo, os interesses do capital internacional ditam os mecanismos de atuação das forças políticas internas. Outro lado, da dependência política é exclusão das camadas inferiores da sociedade, o que obriga que as mesmas se associem ao grupo que controla o Estado-Empresário ou são marginalizados dentro do processo de acumulação interna. Por fim, conclui-se que a penetração de capital externo em Moçambique associa-se as elites nacionalistas que controlam o Estado. Estas elites políticas, que, por conseguinte formam a burguesia nacional é que tem o papel de definir dentro dos limites, e das possibilidades dadas pelos países centrais o tipo e a forma de desenvolvimento social e econômico do país

\section{REFERÊNCIAS BIBLIOGRÁFICAS}

ABRAHAMSON, Hans. The Scramble from Africa. Gothenburg University, PADRIGU. Peace and Development Institute. Gothenburg (Sweden), 1995.

ABRAHAMSON, Hans, NILSON, Anders. The Washington Consensus and Mozambique. Gothenburg University, PADRIGU. Peace and Development Institute. Gothenburg (Sweden), 1996.

ARIENT, Wagner Lael; FILOMENO, Felipe Amin. Economia política do moderno sistema mundial: as contribuições de Wallestein, Braudel e Arrighi. Ensaios FEE, Porto Alegre, V.28, p. 99126, Julho de 2007.

ARRIGHI, Giovanni. A ilusão do desenvolvimento. Vozes. Petrópolis, Rio de Janeiro, 1997.

BAMBIRRA, Vânia. O capitalismo dependente latino-americano. $3^{\text {a }}$ Edição. Florianópolis: Insular, 2015. 
Banco Mundial. Mozambique Financial Sector Study. Washington. The World Bank, 1992.

BELLUCCI, Beluce. Economia Contemporânea de Moçambique: Sociedade Linhageira, Colonialismo, Socialismo, Liberalismo. Rio de Janeiro: Educam, 2007.

Fundo Monetário Internacional - FMI. Enhanced Structural Adjustment Facility Policy Framework Paper for 1998-2000. Republic of Mozambique. Washington DC, 1998.

BENAKOUCHE, Rabah. Crise e dívida externa: o caso brasileiro. São Paulo- Diniz, 1984.

BRANCO, Luís Castelo. Das Razões políticas da SADCC às razões econômicas da SADC. Edições da Universidade de Lusíadas. Lisboa, 1997.

CHANAIWA, David; KODJO. Edem. Pan-africanismo e libertação In MAZRUI. Ali A. WONDJI. C. (org.) História Geral da África - VIII: África desde 1935, Brasília: UNES-CO, 2010 pp. 897-924.

CARDOSO, Fernando Henrique. As ideais e seu lugar: Ensaio sobre as teorias de desenvolvimento. Petrópolis, Rio de Janeiro: Vozes, 1993.

CARDOSO, Fernando Henrique; ENZO, Falleto. Dependência e Desenvolvimento na América Latina: Ensaio de Interpretação Sociológica. Rio de Janeiro, $3^{\text {a }}$ Edição. Zahar Editores, 1975.

DEVÉS-VALDÉS, EDUARDO. El pensamiento latinoamericano en el siglo XX. Tomo II. Desde la CEPAL al neoliberalismo (1950-1990). Editorial Biblos Centro de Investigaciones Diego Barros Arana, Santiago, 2003.

DE MELlO, João Manuel Cardoso. O Capitalismo Tardio: Contribuição à revisão crítica da formação e desenvolvimento da economia brasileira. $8^{a}$ Edição. São Paulo: Editora Brasiliense, 1991.

FRENTE DE LIBERTAÇÃO DE MOÇAMBIQUE (FRELIMO). Moçambique: 35 Anos da Independência Nacional: Principais Realizações 1975 - 2010. $1^{\text {a }}$ Edição. Maputo, Junho de 2010. 
FURTADO, Celso. O mito de desenvolvimento econômico. Paz e terra. Rio de Janeiro, 1974.

FURTADO, Celso. Desenvolvimento e Subdesenvolvimento. Economia Política e desenvolvimento. Centro Internacional Celso Furtado. Contraponto. Rio de Janeiro: 2009.

FURTADO, Celso. Raízes do subdesenvolvimento. $2^{\mathrm{a}}$ Edição. Civilização brasileira. Centro Internacional Celso Furtado. Rio de Janeiro, 2011.

MARINI, Ruy Mauro. "Dialética da dependência": Uma antologia sobre a obra de Ruy Marini; Petrópolis, Rio de Janeiro: Vozes; Buenos Aires: CLACSO, 2000.

MARINI, Ruy Mauro. Subdesenvolvimento e revolução. Florianópolis: Insular, 2012.

MARTINS, Carlos Eduardo. Globalização, Dependência e Neoliberalismo na América Latina. São Paulo: Biotempo, 2011.

MOSCA, João. S.O. S África. Instituto Piaget, Colóquio de Economia e Política. 2004.

PAIVA, José Francisco Lynce Zagallo. Economia e Política: Moçambique e as Instituições de Bretton Woods. Veja Universidade - Ciências Sociais e Política. Dissertação de Mestrado, Lisboa, 2000.

PERROUX, François. Ensaio sobre a Filosofia do Novo Desenvolvimento. UNESCO. Lisboa, 1981.

SANTOS, Theotônio Dos. Países Emergentes e os novos caminhos da modernidade. Brasília: Cátedra da UNESCO em Economia Global e Desenvolvimento Sustentável, UNESCO, 2008.

SANTOS, Theotônio Dos. Teoria da Dependência: Balanços e Perspectivas. Obras Escolhidas. V.1. Florianópolis: insular. Reedição Ampliada e atual. 2016.

TAVARES, Maria da Conceição, FIORI, José Luís (Org.) Poder e Dinheiro: Uma economia política da globalização. Vozes. Petrópolis. Rio de Janeiro: 1997.

TRASPADINI, Roberta. A teoria da (Inter) Dependência de Fernando Henrique Cardoso. $2^{\text {a }}$ Edição. São Paulo: Editoras Outras Expressões. 